\title{
Performance of Kacang Goat Fattening Intensive Using Complit Feed with Different Levels of Liquid Smoke
}

\author{
Muhammad Hatta ${ }^{1}$, Sud irman Baco ${ }^{1}$, Syamsuddin Garantjang', Effendi Abustam ${ }^{2}$ \\ ${ }^{1}$ Department of Animals Production, Faculty of Animals Husbandry Hasanuddin University, Makassar-Indonesia \\ 2 Department Animal Pruduct and Technology, Faculty of Animals Husbandry Hasanuddin University Makassar-Indonesia
}

Correspondence Author: Muhammad Hatta, Department of Animals Production, Faculty of Animals Husbandry Hasanuddin University, MakassarIndonesia

Received date: 12 August 2018, Accepted date: 10 December 2018, Online date: 25 December 2018

Copyright: (c) 2018 Muhammad Hatta et al., This is an open-access article distributed under the terms of the Creative Commons Attribution License, which permits unrestricted use, distribution, and reproduction in any medium, provided the original author and source are credited.

\begin{abstract}
Kacang goat are native to Indonesia. The productivity of Kacang goats can be optimized if given a good enough feed and is available continuously. The purpose of this study was to evaluate carcass performance and carcass composition as well as Kacang goat. A total of 16 young male goats were divided into 4 treatments. Each treatment consisted of 4 replications. The design used was a completely randomized design with 4 feed formulas as a treatment and each treatment was repeated 4 times. P1 is a liquid smokeless feed formula, P2 is a feed formula with $1 \%$ liquid smoke, $\mathrm{P} 3$ feed formula with $2 \%$ liquid smoke and P4 feed formula with $3 \%$ liquid smoke. Cattle are kept in individual cages given adlibitum complete feed and water according to treatment. After being kept for three months the next cut. The parameters measured were the percentage of carcass, commercial carcass pieces and carcass composition. Data analysis showed that livestock given complete feed containing 1\% liquid smoke (P2) had the highest percentage of carcass and front carcass from other treatments but had the lowest percentage of noncarcass, while the highest rear carcass was $P 4$. The highest cutting weight is P3 treatment. Leg commercial cuts and loin + tender loin entered in quality I were highest in treatment P3 while the lowest was P1. The highest cut of the neck quality II in P2 Rack treatment and the highest shoulder percentage is P1. Commercial cut of quality III are the highest breasts in treatment P3, the highest shank and flank on P1. The highest percentage of meat in treatment P4 and the lowest was treatment P1 while the highest fat percentage was in treatment P3 and the highest bone was P1. In conclusion, the higher the level of liquid smoke in complete feed, the higher the percentage of rear carcass and meat percentage. The provision of complete feed containing liquid smoke has a positive influence on increasing the percentage of carcass and increasing the percentage of commercial quality $I$.
\end{abstract}

Key words: Kacang Goat, Complete Feed, Liquid Smoke, Carcass, Non-Carcass (Offal)

\section{INTRODUCTION}

Kacang Goat is goat local native to Indonesia and scattered throughout provinces in Indonesian [35], the population the most between type others [9] [30]. Kacang Goat has value carcass percentage ranges from 43-44\% [33] [ 18/19].

Indonesian has two season that is season dry between In April-October and season rainy day between month October - April. So that quantity and quality feed fluctuate [32] For that needed feed Complete formulation that capable hit he needs nutrition /feed livestock. Utilization of waste agriculture combined with industrial waste and the rough tree is wrong one solution provision feed in a manner continuous.

Liquid smoke is one of the materials that can be used as animal feed because it has components including phenol, acids, and carbonyl. These substances for the prevention of free radicals, so that the feed nutrients are not degradation.

According to [13] polyphenols and tannins are able to bind proteins to avoid degradation of microbial enzymes and protease enzymes in the rumen. Tannin is also able to precipitate proteins with functional bonds to produce complex crosslinking into tannin proteins [6]

Liquid smoke containing VFA, it is precursor source energy for bacteria and the host. The presence framework carbon for rumen microbes so able to forming microbial proteins more many for ruminants. The components possessed by liquid smoke are expected to be able to improve carcass, commercial cut carcass and carcass composition of Kacang goat.

The use of liquid smoke up to $1 \%$ of the feed can improve the quality of meat, the amount of albumin in the blood of broiler chickens [38] and increase the performance of mice up to a dose of $15 \mathrm{~g} / \mathrm{kg}$ of feed [5] Concentration of liquid smoke in UMB unpacking feed supplement Bali cattle capable for increases brightness meat of muscle Longissimus dorsi[2].

The purpose of this study is to analyze the percentage of carcass, carcass composition and commercial carcasses percentage of Kacang goats through intensive fattening using complete feed added with liquid smoke.

\section{MATERIALS AND METHODS}

Research has been carried out for approximately 7 months with the distribution of activities and time and place as follows: Feed making and livestock raising in the Laboratory of Animal Husbandry, in April - November 2018. 
A total of sixteen young male goats were divided into 4 treatments. Each treatment consisted of 4 replications. The design used was a completely randomized design with 4 feed formulas as a treatment and each treatment was repeated 4 times. P1 is a liquid smokeless feed formula, P2 is a feed formula with $1 \%$ liquid smoke, P3 feed formula with $2 \%$ liquid smoke and P4 feed formula with 3\% liquid smoke[ 31]. The animals are kept in individual cages given adlibitum complete feed and water according to treatment. After being kept for three months the next slaughtered. The parameters measured were the percentage of carcass, commercial cut carcass percentage and carcass composition percentage.

The slaughter livestock do it halal to cut neck ventral section, pulse jugular vein, esophagus, and the trachea was cut off. Then do the finishing, next the carcass is divided into eight commercials [26] [ 8]. All commercial cut carcass and carcass component were weighed to measure the weight of each.

\section{Statistical analysis}

Data from four treatment were analyzed using the procedure variance analysis (one-way ANOVA) of SPSS Version 16 for Windows. The package program according to the following models: $\mathrm{Yij}=\mu+\mathrm{Ti}+\mathrm{fij}$. Yij $=$ Observation from the second converter with jth test, $\mu=$ General average (midpoint of observation) Ti $=$ Effect of second treatment $(i=1,2,3,4) £ i j=$ Effect of experimental error from the first treatment and on the jth observation $(j=1,2,3,4)$

Carcass and Non-carcass Performance of Peanut Goats

\section{RESULTS AND DISCUSSION}

Table 1. Results of Analysis of Carcasses and Non-Carcasses of Goat Research Phase I (different levels of liquid smoke)

\begin{tabular}{|c|c|c|c|c|c|}
\hline \multirow{2}{*}{ No. } & \multirow{2}{*}{ Description } & \multicolumn{4}{|c|}{ Treatment } \\
\hline & & P1 & $\mathbf{P 2}$ & P3 & P4 \\
\hline 1 & Carcass & $34.83 \pm 2.03$ & $39.17 \pm 1.44$ & $38.96 \pm 2.67$ & $38.70 \pm 0.46$ \\
\hline 2 & Non carcass & $65.17 \pm 2.03$ & $60.83 \pm 1.43$ & $61.04 \pm 2.66$ & $61.30 \pm 0.46$ \\
\hline 3 & Fore carcass & $55.33 \pm 0.11$ & $56.58 \pm 0.67$ & $55.25 \pm 0.41$ & $54.94 \pm 0.27$ \\
\hline 4 & Hind Carcass & $44.67 \pm 0.11$ & $43.43 \pm 0.67$ & $44.75 \pm 0.41$ & $45.06 \pm 0.27$ \\
\hline 5 & Cut weight $(\mathrm{kg})$ & $14.50 \pm 0.68$ & $15.69 \pm 1.86$ & $16.14 \pm 2.35$ & $14.55 \pm 0.38$ \\
\hline
\end{tabular}

Based on Table 1. It is known that the slaughter weight of livestock ranges from $14.5 \mathrm{~kg}$ to $16.14 \mathrm{~kg}$. The different results reported by [34] that the slaughter weight of 2-year-old Kacang goat is 24.23-24.27. This difference is caused by differences in age. The results of cutting the four treatments P1, P2, P3, and P4 yielded, offal, front carcass and rear carcass respectively $34.83 \pm 2.03,, 39.17 \pm 1.44,38.96 \pm 2.67$, and $38.70 \pm 0.46$ for carcasses, $65.17 \pm 2.03,60.83 \pm 1.43$, $61.04 \pm 2.66$, and $61.30 \pm 0.46$ for offal, while the front carcass and rear carcass were produced as follows: $55.33 \pm 0.11,56,575 \pm 0.67,55.25 \pm 0.41,54.94 \pm$ 0.27 , and $44.67 \pm 0.11,43.43 \pm 0.67,44.75 \pm 0.41$, and $45.06 \pm 0.27$. This result descriptively shows that the percentage of goat carcasses given complete feed without the addition of liquid smoke is always lower when compared to those given complete feed containing liquid smoke at $1 \%, 2 \%$, and $3 \%$. If all three treatments $\mathrm{P} 2, \mathrm{P} 3$, and $\mathrm{P} 4$ are rounded, they will produce $39 \%$. But the highest is treatment with $1 \%$ liquid smoke. other factors that influence the percentage of the carcass are a nation, sex, slaughter weight and feed [34]. Furthermore, it was reported that the percentage of goat carcasses was $39.39 \%-42.48 \%$ and $44.68-45 \%$ [23].

Local goats with weaning age (6-18 months) with a range of weights of 10-23.5 kg (mean $15.99 \mathrm{~kg}$ ) produce carcass weight from 4.5 to $10 \mathrm{~kg}$ (mean $7.05 \mathrm{~kg}$ ) and carcass percentage $44.68-45 \%$ (average 44.09\%). These results are who observed goats in Majalengka and Bandung regencies with live weights of 14.99-18 $\mathrm{kg}(6.3-22.1$ and $16-21 \mathrm{~kg})$ resulting in carcass weight $7.23-7.58 \mathrm{~kg}$ and carcass percentage $48.23-42,10$ percent [23]

Non carcasses produced from treatment P1, P2, P3, and P4 if rounding is the same value, namely $65 \%, 60 \%, 61 \%$ and 61 , the highest is treatment P1 which is 65.17 or 65 percent while $\mathrm{P} 2$ is $60 \%, \mathrm{P} 3$ and $\mathrm{P} 2$ are relatively the same, namely $61 \%$. This means that parts of the carcass that the highest low economic value in treatment $\mathrm{P} 1$. When viewed in terms of carcass, the best treatment is treatment $\mathrm{P} 2$ where the total carcass is the highest. Whereas if viewed in terms of quality, the highest is P4 because it has the highest rear carcass. We know that meat that occupies the position of quality I am meat found in the rear carcass. So economically it is best to treat P4.

Based on the overall matrix, it can be seen that the best treatment is treatment P3 where in terms of carcass P3 and P4 are relatively the same while in terms of weight gain and feed consumption the highest is treatment P3 because it has the highest efficiency value and the lowest feed conversion. [3] reported that the availability of liquid smoke in the Coconut Solid Molasses Urea (UCSMB) feed was able to increase the body weight of Balinese cattle. Furthermore, it was stated that the addition of liquid smoke as an antioxidant in the block supplement diet could maintain the functional properties of the Bali cattle LD muscle during maturation.

The higher the percentage of liquid smoke, the higher the percentage of the rear carcass. This means that there is a contribution of liquid smoke to the growth and development of the back muscles of goats. The percentage of rear carcass indicates that the muscles in the back of the cattle are more developed in the presence of liquid smoke in complete feed.

\section{Commercial Cut}

Table 2. Mean Commercial Cut carcass goat on different Level Liquid Smoke

\begin{tabular}{|c|c|c|c|c|c|}
\hline \multirow{2}{*}{ Quality } & \multirow{2}{*}{ Variable } & \multicolumn{4}{|c|}{ Treatment (liquid smoke) } \\
\cline { 2 - 6 } & & P1 (0\%) & P2 (1\%) & P3 (2\%) & P4 (3\%) \\
\hline \multirow{2}{*}{ I } & Leg & $26.58 \pm 9.61$ & $28.58 \pm 0.84$ & $30.65 \pm 1.09$ & $29.44 \pm 1.08$ \\
\cline { 2 - 7 } & Loin+ Tender loin & $5.69 \pm 0.50$ & $7.13 \pm 1.57$ & $8.03 \pm 0.47$ & $9.13 \pm 1.74$ \\
\hline \multirow{3}{*}{ II } & Neck & $10.96 \pm 0.58$ & $11.76 \pm 1.13$ & $9.8 \pm 0.28$ & $9.64 \pm 4.05$ \\
& Rack & $11.0 \pm 0.29$ & $8.17 \pm 0.27$ & $27.17 \pm 1.04$ & $8.52 \pm 1.20$ \\
\cline { 2 - 7 } & Shoulder & $27.37 \pm .0 .58$ & $22.64 \pm 1.41$ & $4.19 \pm 0.06$ & $21.91 \pm 4.37$ \\
\cline { 2 - 7 } & Breast & $6.63 \pm 0.29$ & $6.75 \pm 0.66$ & $6.85 \pm 0.53$ & $4.35 \pm 1.16$ \\
\cline { 2 - 7 } & Shank & $4.97 \pm 0.28$ & $4.42 \pm 0.42$ & $5.14 \pm 0.49$ & $5.27 \pm 0.30$ \\
\hline
\end{tabular}

The distribution of the quality of commercial pieces divided based on the Australian method and SNI can be seen in Table 2. Based on Table 2 it is known that the percentage of leg pieces loin plus tenderloin increases with increasing levels of liquid smoke in the feed. This is due to muscle growth and supporting tissue increases with increasing levels of liquid smoke. Whereas Neck, rack, and shoulder decreases. This is because this part is dominated by bone and fat accumulation has not occurred. This part of the muscle is not well developed because muscle development starts from the front foot and from the back of the animal's body and ends at the center. Breast, shank and relatively stable.

The feed is a factor that environment have influence enough big to composition carcass, specifically proportion fat [27] [37]. While difference rate growth relatively each component network carcass influenced by species, age and feed [ 27]. The cutter leg Kacang goat is the leg $30.08 \%$, loin $11.98 \%$, rib $9.32 \%$, shoulder $27.7 \%$, neck $8.11 \%$, shank $4.11 \%$, break $7.01 \%$ and flank $1.67 \%$ [37] . this to show that cut the leg on research this same, so too with a shank. The shoulder on feed control has percentage same with results research [37] who use feed natural and pure breeds. While on use smoke liquid in feed cause shoulder less developing but more developing are leg and loin. this means that use the smoke liquid in feed cause muscle part back more developing in the appeal. 


\section{Carcass Composition}

Table 17: Carcass composition Kacang Goat analysis results of research on Level liquid smoke different.

\begin{tabular}{|c|c|c|c|c|c|}
\hline \multirow{2}{*}{ No. } & \multirow{2}{*}{ Description } & P1 & P2 & Treatment \\
\cline { 3 - 5 } & & $60.58 \pm 0.13$ & $63.72 \pm 5.09$ & 69 \\
\hline 1 & Meat & $10.89 \pm 0.25$ & $9.89 \pm 2.60$ & $64.41 \pm 4.89$ & $11.24 \pm 1.69$ \\
\hline 2 & Fat & $28.53 \pm 0.12$ & $26.40 \pm 0.001$ & $9.70 \pm 0.40$ & $24.37 \pm 4.02$ \\
\hline 3 & Bone & $25.75 \pm 3.12$ & \\
\hline
\end{tabular}

Table 17 shows that the higher the level of liquid smoke the higher the percentage of meat, the more stable the percentage of bone. While the percentage of carcass fat decreases. This shows that liquid smoke has an influence on the growth of livestock especially the addition of the percentage of meat and lowering the percentage of fat. This may be due to the presence of fatty acids such as acetic acid, propionate, and vale rate as microbial energy sources. Propionate acid is the main ingredient in the synthesis carbohydrate castrated bull. Tannin is able to protect feed proteins so it doesn't tear degradation by microbes (protein bypass) [29]. Carcass composition is influenced by age and type of livestock. Meat production will change from young livestock to adult cattle [12], [16], [7] influenced by various factors such as: nation and type of livestock [11], [21], [14], [7], [4], [25], gender [28], [20], [24], [10], [1], feed [36], [14], [15], [17], [22], and body weight and age [1].

\section{CONCLUSION}

Based on the results and discussion, it can be concluded that the addition of $2 \%$ liquid smoke to complete feed can increase carcass percentage and commercial cut carcass percentage leg and loin on Kacang goat. The addition of liquid smoke in complete feed can increase the percentage of Kacang goat meat that is intensively preserved.

The authors declare that there are no conflicts of interest.

\section{CONFLICT OF INTEREST}

\section{ACKNOWLEDGEMENT}

The authors would like to say thank you to Ministry Research and Technology Dikti of Indonesia for financial support studies and Hasanuddin University for promise study graduate.

\section{REFFERENCES}

[1] Abebe, G., 2000. Carcass Characteristics of Somali Goats Slaughtered at Different Ages. In: Proceedings the 7th International Conference on Goat. Poitiers, France. pp. 829.

[2] Abustan, E., M. Yusuf, and H.M. Ali, M.I Said and F.N. Yuliati. 2016. Quality of Bali Beef and Broiler after Immersion in Liquid Smoke on Different Concentrations and storage Times. World Academy of Science, Engineering and Technology International Journal of Biological, Biomolecular, Agricultural, Food and Biotechnological Engineering. 10, (2): pp. 75-79.

[3] Abustan, E., M. Yusuf and M. I. Said. 2018. The Effect of Antioxidant Activity of Liquid Smoke in Feed Supplement Block on Meat Functional of Muscle Longissimus dorsi. IOP Conference Series: Earth and Environmental Science. IOP Publishing. 119: 1 -7. Doi: 10.1088/1755-1315/119/1/012046

[4] Amin, M.R., Husain, S.S., and Islam, A.B.M.M., 2000. Evaluation of Black Benfal goat and their cross with the Jamnapari breed for carcass characteristics. Small Rumen. Res. 38:211-215.

[5] Budijanto. S, R. Hasbullah, S. Prabawati, Setyadjit, Sukarno, and I. ZuraidaJ. Identification and safety test on liquid smoke made from coconut shell for food product. J. Pascapanen 5(1) 2008: 32-40

[6] Deaville, E. R., D. I. Givens, \& I. Mueler-Harvey. 2010. Chesnutt and Mimosa tannin silages: Effect in sheep differ for apparent digestibility, nitrogen utilization and losses. Anim. Feed Sci. Technol. 157: 129-138. DOI: 10.1016/j.anifeedsci.2010.02.007.

[7] Ermias, E. and Rege J.E.O., 2003. Characteristics of live animal allometric measurements associated with body fat in fat-tailed sheep. Lives. Prod. Sci. 81(23):271-281. Doi.org/10.1016/S0301-6226(02)00256-7.

[8] FAO, 1991. The state of Food and Agriculture. Food and Agriculture Organisation of The United National. ISBN 92-5-103092-8

[9] Ginting SP, Mahmilia F . 2008. Kambing Boerka: Kambing tipe pedaging hasil persilangan Boer x Kacang. Wartazoa. 18:115-126.

[10] Hall, D. G., Gilmour, A. R., Fogarty, N. M., Holst, P. J., and Hopkins, D.L., 2001. Growth and carcass composition of second-cross lambs. 1. Effect of sex and growth path on pre and post-slaughter estimates of carcass composition. Aust. J. Agric. Res. 52: 859-867. Doi: 10.1071/AR98091

[11] Herold, P., Snell, H., and Tawfik, E.Z., 2007. Growth, carcass and meat quality parameters of purebred and crossbred goat kids in extensive pasture. Arch. Tierz., Dummerstorf. 50(2):186-196. Doi: 10.5194/aab-50-186-2007.

[12] Kebede, T., Lemma, T., Hunduma, Dinka, H., Guru, M., and Sisay, A., 2008. Growth performance and carcass characteristics of arsi-bale goats castrated at different ages. World Applied Sci. J. 4 (4): 545-553.

[13] Kondo, M., K. Kita, \& H. Yokota. 2004. Feeding value to goats of whole crop oat ensiled with green tea waste. Anim. Feed. Sci. Technol. 113 (1-4):71-81. Doi.org/10.1016/j.anifeedsci.2003.10.018

[14] Lewis R. M., Macfarlane J.M., Simm G., and Emmans, G.C., 2004. Effects of food quality on growth and carcass composition in lambs of two breeds and their cross. Anim. Sci. 78 (3):355-367. Doi.org/10.1017/S1357729800058768

[15] Mahgoub, O., Lu, C.D., and Early, R.J., 2000. Effects of dietary energy density on feed intake, body weight gain and carcass chemical composition of Oman growing lambs. Small Rumin. Res. 37: 35-42. doi.org/10.1016/S0921-4488(99)00132-7

[16] Marichal, A., Castro, N., Capote, J., Zamorano, M. J., and Argüello, A., 2003. Effects of live weight at slaughter (6, 10 and 25 kg) on kid carcass and meat quality. Lives. Prod. Sci. 83:247-256. doi.org/10.1016/S0301-6226(03)00113-1

[17] Meneses, R., Pérez, P.M., Pittet, J.D., Galleguillos, P.R., and Morales, M.S., 2001. Feeding strategies for the rearing of Creole kid goats. Agric. Technol. 61(2): 21-26.

[18] Mujahidin. 2006. Nilai mutu daging dan perdagingan kambing Kacang dan domba lokal dengan jenis kelamin yang berbeda yang dipelihara secara intensif (dikandangkan) (skripsi S1). [Bogor (Indonesia)]: Institut Pertanian Bogor.

[19] Musahidin. 2006. Nilai mutu daging dan perdagingan kambing Kacang dan domba lokal dengan jenis kelamin yang berbeda yang dipelihara secara intensif (dikandangkan) (skripsi S1). [Bogor (Indonesia)]: Institut Pertanian Bogor.

[20] Peña, F., Perea, J., García, A., and Acero, R., 2007. Effects of weight at slaughter and sex on the carcass characteristics of Florida suckling kids. Meat Sci. 75(3):543-550. DOI: $10.1016 /$ i.meatsci.2006.09.004

[21] Santos, V. A. C., Silva, A. O., Cardoso, J. V. F., Silvestre, A. J. D., Silva, S. R., Martins, C., and Azevedo, J. M.T., 2007. Genotype and sex effects on carcass and meat quality of suckling kids protected by the PGI "Cabrito de Barroso". Meat Sci. 75(4):725-736. DOI: 10.1016/i.meatsci.2006.10.003

[22] Shahjalal, M., 2000. Growth and Carcass Characteristics of Goats Given Diets Varying Protein Concentration and Feeding Levels. In : Anim. Sci. 3(5): 613618 
[23] Shodiq. A. 2011. Prediksi Bobot dan Konformasi Karkas Kambing Lokal Menggunakan Prediktor Bobot Potong dengan Berbagai Model Regresi. J. Agripet : 11(2) : 1-7.g (Indonesia)

[24] Simela, L., Webb, E.C., and Frylinck, L., 2004. Effect of sex, age, and pre-slaughter conditioning on pH, temperature, tenderness properties and colour of indigenous South African goats. S. Afr. J. Anim. Sci. 34 (5) : 208-211.

[25] Singh-L.B., Singh, D.K., and Singh, C.S.P., 1994. Genetic Studies on Carcass Characteristics of Black Bengal Goats. Indian J. Anim. Sci. 64(2):157-162.

[26] SNI. 2008. Mutu Karkas dan Daging Kambing dan Domba. Badan Standard Nasional.bsn@bsn.go.id. (Indonesia)

[27] Soeparno. 1994. Ilmu dan Teknologi Daging. Gadjah Mada University Press. Yogyakarta

[28] Solaiman S, Kerth, C., Willian, K., Min, B.R., Shoemaker, C., Jones, W., and Bransby, D., 2011. Growth Performance, Carcass Characteristics and Meat Quality of Boer-Cross Wether and Buck Goats Grazing Marshall Ryegrass. Asian-Aust. J. Anim. Sci. 24(3):351-357. Doi.org/10.5713/ajas.2011.10081

[29] Sotranto,1999). Efisiensi Pengubahan Asam Propionat untuk Sintesis Glukosa pada Sapi Jantan Kebiri Jenis Brahman yang diberikan pakan bermutu rendah. Fakultas Pternakan Universitas Brawijaya, Malang.(Indonesia)

[30] Stanton Emms, Sia. 2010. Competitive industry report on the Indonesian cattle and goats sectors: opportunities for canadian animal genetics. Agriculture and Agri-food Canada. [diakses pada 17 Desember 2013]. http://stantonemmsandsia.foodandbeverage.

[31] Steel, R.G.D., dan J.H. Torrie. 1991. Principles and Procedures of Statistics. McGraw-Hill, Book Co. Inc, New York

[32] Suherman dan Erman. 2003. Strategi Pembelajaran Matematika Kontemporer Bandung: PT Remaja Rosdakarya. (Indonesia)

[33] Sunarlim R, Setiyanto H. 2005. Potongan komersial karkas kambing Kacang jantan dan domba lokal jantan terhadap komposisi fisik karkas, sifat fisik dan nilai gizi daging. Mathius IW, Bahri S, Prasetyo LH, Triwulanningsih E, Tiesnamurti B. Sendow I, Suhardono, penyunting. Prosiding Seminar Nasional Teknologi Peternakan dan Veteriner. Bogor (Indonesia): Pusat Penelitian dan Pengembangan Peternakan. hlm. 666-673.

[34] Sunarlin. R dan S. Usmiati. 2006. Profile of Sheep and Goat Carcass. Seminar Nasional Teknologi Peternakan dan Veteriner 2006Balai Besar Penelitian dan Pengembangan Pascapanen Pertanian. Cimanggu, Bogor.(Indonesia)

[35] Sutama IK, Budiarsana IGM. 2011. Panduan lengkap kambing dan domba. Edisi ketiga. Jakarta (Indonesia): Penebar Swadaya.

[36] Todaro, M., Corrao, A., Barone, C.M.A., Alicata, M.L., Schinelli, R., and Giaccone, P., 2006. Use of weaning concentrate in the feeding of suckling kids: Effects on meat quality. Small Rumin. Res. 66: 44-50. DOI: 10.1016/j.smallrumres.2005.06.038

[37] Triyantini, Subandriyo, Setiyanto H, dan Mulyadi. 2005. Tampilan karakteristik komponen karkas dan mutu karkas dari beberapa genotype domba komposit Sumatra. Penyunting I Wayan Mathius et al.,. Prosiding Seminar Nasional Teknologi dan Veteriner; Bogor, 12-13 September 2005, hal 479-485.(Indonesia)

[38] Yan S., X. Wu J,. Chen, P. Wang. 2012. Ethanol production from concentrated food waste hydrolysates with yeast cel ls immobilized on corn stalk. Appl Microbiol Biotechnol 94(3):829-38. DOI:10.1007/s00253-012-3990-7 